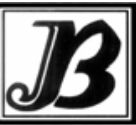

J. bio-sci. 16: 115-119, 2008

ISSN 1023-8654

http://www.banglajol.info/index.php/JBS/index

\title{
OCCURRENCE AND ABUNDANCE OF SOME COPEPODS IN A FISH POND IN RAJSHAHI, BANGLADESH IN RELATION TO THE PHYSICO-CHEMICAL CONDITIONS
}

\author{
Abdus Salam Bhuiyan ${ }^{1 *}, M T$ Islam ${ }^{1}$ and R Sharmeen ${ }^{2}$ \\ ${ }^{1}$ Department of Zoology, ${ }^{2}$ Department of Fisheries, University of Rajshahi, Rajshahi-6205, Bangladesh

\begin{abstract}
An investigation was carried out to find out the occurrence and abundance of copepods in relation to physico-chemical parameters in a fish pond within the Rajshahi University Campus, Rajshahi, Bangladesh from December, 2006 to September, 2007. A total of 5 genera of copepods of which 2 species belong to Cyclops were identified. Highest density of copepods (768 units/l) was observed in May 2007. Seasonal succession of copepods showed the most abundance in spring, followed by winter, summer and autumn. Correlationship between different physico-chemical parameters and copepods were also analyzed.
\end{abstract}

Key words: Copepod occurrence, physico-chemical parameters, fish pond.

\section{Introduction}

The abundance of zooplankton in a water body is regarded as an indicator of productivity. Growth and abundance of zooplankton varies with season and depth and depends upon meteorological and water properties. Both the qualitative and quantitative abundance of plankton in a fish pond are of great importance in managing the successful aquaculture operations, as they vary from location to location and pond to pond within the same location even within similar ecological conditions (Boyd 1982). George (1966), Krishnamurty and Visvesvara (1966), Sreenivasan (1967) and Michael (1968) worked in detail on the ecology and zooplankton population from different waters of India. Some of the works which have been done in Bangladesh include those of Das and Bhuiyan (1974), Islam and Mendes (1976), Khan et al. (1978), Bhuiyan and Nesa (1998a, b) and Bhuiyan et al. (1997). Although some works on copepods have been done all over the world, but little or no work has been done on the abundance of copepods in relation to physico-chemical conditions of fish ponds of Rajshahi, Bangladesh. Therefore the present investigation has an aim to attract attention to the occurrence and abundance of copepods in a fish pond in relation to physico-chemical conditions of Rajshahi, Bangladesh.

\section{Materials and Methods:}

The present study was undertaken through a period of ten months from December 2006 to September 2007 in a fish pond. The pond is situated just behind the 3rd science buildings near Taposhi Rabeya Hall. It is Lshaped and has an area of $4050 \mathrm{~m}^{2}$ with an average depth of $3.5 \mathrm{~m}$ which varies through the year due to rise and fall of water level. The pond is under pisciculture, so it is stocked with Rohu, Catla, Mrigal, Silvercarp, Mirror carp, Bighead carp and Sarpunti.

Water samples were collected from three layers (below the surface, at middle and at bottom) thrice a day at weekly interval from December, 2006 to September, 2007 during the observation period. Physical parameter

\footnotetext{
${ }^{*}$ Corresponding author.
} 
such as temperature was measured by water quality checker (20A, TOA-Japan). Chemical parameter such as Dissolved Oxygen (DO) was measured by titration method (APHA 1976). Free Carbon dioxide $\left(\mathrm{CO}_{2}\right.$ ), Carbonate and Bi-carbonate alkalinity were measured by titration method (Welch 1948). pH was measured by the digital $p H$ meter (Model HI 1280). The zooplankton sample was collected by plankton net of 20 count bolting cloth. Planktonic samples for qualitative and quantitative analysis were collected in one liter capacity Pyrex glass bottles and preserved permanently in Transeau's solution. The zooplankters were identified following the keys given by Ward and Whipple (1959), Mellanby (1963), Needham and Needham (1972), Tonapi (1980) and Bhuiyan and Asmat (1992).The vials containing the preserved zooplankton were stirred gently for equalization in distribution from which sub sample was drawn with dropper in to the SedgwickRafter counting cell. The zooplankter in S-R cell was counted under a phase contrast light microscope, Olympus, Japan. The zooplankters per liter of original water were estimated by the following formula of Stirling (1985). Seasons were divided as follows: summer (June through August), autumn (September through November), winter (December through February) and spring (March through May) (Welch 1948) Statistical Analysis was done using SPSS programmae.

\section{Results}

Physical parameters: Some selected physico-chemical parameters are studied and shown in the Fig 1 to Fig 3. Temperature fluctuated from $17.09{ }^{\circ} \mathrm{C}$ to $31.66^{\circ} \mathrm{C}$. Minimum $\left(17.09^{\circ} \mathrm{C}\right)$ was observed in January and maximum $\left(31.66^{\circ} \mathrm{C}\right)$ in May, 2007. Alkaline $\mathrm{pH}$ was observed throughout the study period. Lowest pH (8.15) was observed in September, 2007 and the highest (9.11) in April, 2007. The Dissolved Oxygen (DO) content of the water varied from $3.35 \mathrm{mg} / /$ to $4.77 \mathrm{mg} / \mathrm{l}$. Minimum DO concentration $(3.35 \mathrm{mg} / \mathrm{l})$ was observed in April, 2007 and maximum (4.77mg/l) in July, 2007. Free Carbon dioxide was recorded from $0 \mathrm{mg} / \mathrm{l}$ to $13.3 \mathrm{mg} / \mathrm{l}$ in June, 2007 and May, 2007 respectively. Carbonate alkalinity varied from 5.5mg/l (December, 2006) to $90.71 \mathrm{mg} / \mathrm{l}$ (January, 2007) and nil in February, March and May, 2007. Bicarbonate alkalinity was minimum 0 $\mathrm{mg} / \mathrm{l}$ in January, 2007 and maximum 295.97mg/l in February, 2007.
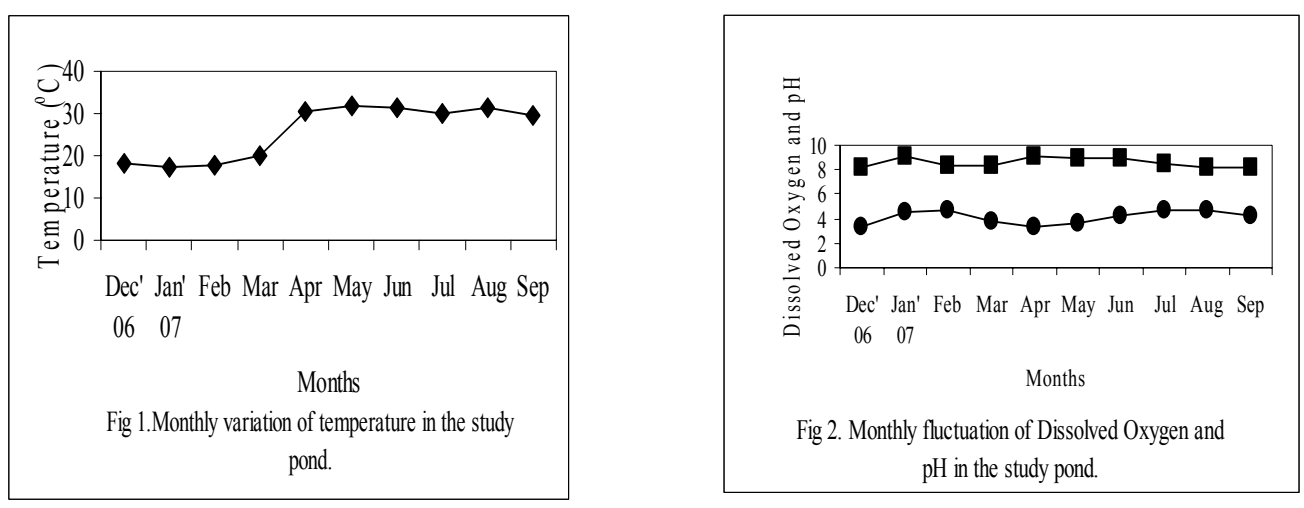

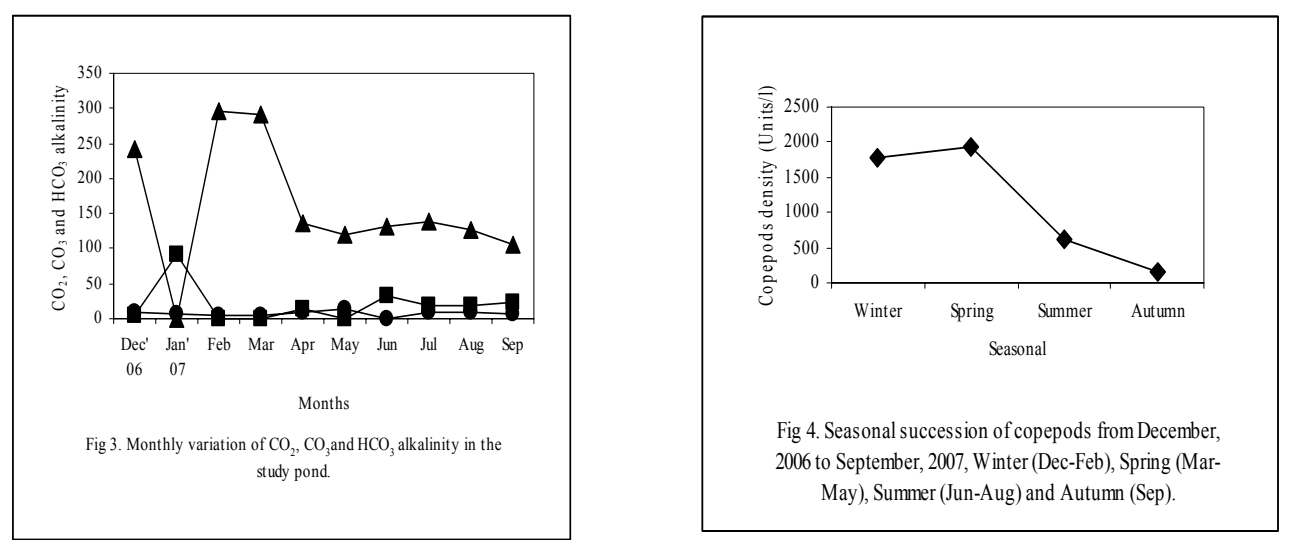

Table 1. Monthly abundance of different copepod/l water (\%) from December, 2006 to September, 2007 in the study pond.

\begin{tabular}{lcccccccccc}
\hline Copepods & Dec'06 & Jan'07 & Feb & Mar & Apr & May & Jun & Jul & Aug & Sep \\
\hline Cyclos scutifer & $316(47)$ & $293(56)$ & $333(57)$ & $252(52)$ & $333(49)$ & $345(45)$ & $84(37)$ & $61(29)$ & $64(35)$ & $45(29)$ \\
Diaptomus & $174(26)$ & $127(24)$ & $139(23)$ & $104(22)$ & $186(28)$ & $272(36)$ & $100(43)$ & $68(33)$ & $66(36)$ & $599(38)$ \\
Merocyclops & $120(18)$ & $63(12)$ & $87(15)$ & $58(12)$ & $73(11)$ & $79(10)$ & $26(11)$ & $30(14)$ & $34(19)$ & $33(21)$ \\
Mesocyclops & $26(4)$ & 0 & 0 & $17(4)$ & $23(3)$ & $32(4)$ & $21(9)$ & $18(9)$ & $19(10)$ & $19(12)$ \\
Cyclops strenus & $35(5)$ & $40(8)$ & $30(5)$ & $50(10)$ & $60(9)$ & $40(5)$ & 0 & 0 & 0 & 0 \\
Heliodiaptomus & 0 & 0 & 0 & 0 & 0 & 0 & 0 & $30(15)$ & 0 & 0 \\
\hline Total & 671 & 523 & 589 & 481 & 675 & 768 & 231 & 207 & 183 & 156 \\
\hline
\end{tabular}

Table 2. Correlation coefficient ( $r$ ) between physico-chemical parameters and the copepods in the study pond.

\begin{tabular}{llllc}
\hline Parameters & Cyclops & Diaptomus & Merocyclops & Mesocyclops \\
\hline Temperature $\left({ }^{\circ} \mathrm{C}\right)$ & $-0.7, \mathrm{P}<0.05$ & -0.04 & -0.54 & 0.62 \\
$\mathrm{pH}$ & 0.39 & 0.52 & 0.01 & 0.46 \\
$\mathrm{DO}(\mathrm{mg} / \mathrm{l})$ & -0.58 & $-0.67, \mathrm{P}<0.05$ & -0.61 & -0.63 \\
$\mathrm{CO}_{2}(\mathrm{mg} / \mathrm{l})$ & $0.39, \mathrm{P}<0.01$ & 0.56 & $0 ., \mathrm{P}<0.05$ & 0.35 \\
$\mathrm{CO}_{3}(\mathrm{mg} / \mathrm{l})$ & -0.8 & -0.58 & -0.74 & 0.13 \\
$\mathrm{HCO}_{3}(\mathrm{mg} / \mathrm{l})$ & 0.27 & 0.05 & 0.42 & 0.01 \\
\hline
\end{tabular}

Copepods: Highest density (768 units/l) of copepods was observed in May, 2007 and lowest (156units/) in September, 2007(Table 1). 5 genera (2 species) of copepods were recorded during the study period. The recorded copepods were Cyclops scutifer, Cyclops strenus, Diaptomus, Merocyclops, Mesocyclops, Heliodiaptomus (Table 1).

Cyclops scutifer: Cyclops scutifer was the most dominant species throughout the study period. Highest cell density (345units/l) was observed in May, 2007 which contributed 45\% of total copepods. Lowest density (45 units/l) was observed in September, 2007 which contributed 29\% of total copepods.

Diaptomus: Diaptomus was the second dominant species throughout the study period. Highest cell density (272 units/l) of Diaptomus was observed in May, 2007 and the lowest (59 units/l) in September, 2007. 
Merocyclops: Merocyclops was abundant throughout the study period with the maximum (120units/) in December, 2006 which contributed 18\% of total copepods and minimum (26 units/l) in June, 2007 which contributed $11 \%$ of total copepods.

Mesocyclops: Mesocyclops was highest (32 units/l) in May, 2007 which contributed 4\% of total copepods and lowest in March (17 units/l) which contributed $4 \%$ of total copepods. Mesocyclops was absent in January and February, 2007.

Cyclops strenus: Cyclops strenus was absent from June to September. It was abundant from December to May, 2007. Highest cell density (60 units/l) was observed in April, 2007 which was $9 \%$ of total copepods and lowest (30 units/l) in February, 2007 which was $5 \%$ of total copepods.

Heliodiaptomus: Heliodiaptomus was present only in July, 2007. Observed cell density was 30 units/l which was $14 \%$ of total copepods. It was absent in all other months.

Seasonal succession of copepods showed that it was abundant in spring (1924 units/l) followed by winter (1783 units/l), summer (621 units/l) and lowest in autumn (156 units/l) (Fig 4). Cyclops, Diaptomus and Merocyclops showed positive correlationship with $\mathrm{pH}$, free $\mathrm{CO}_{2}$ and $\mathrm{HCO}_{3}$ alkalinity. It was negatively correlated with temperature, dissolved oxygen (DO) and $\mathrm{CO}_{3}$ alkalinity (Table 2). Mesocyclops showed positive correlationship with temperature, $\mathrm{pH}, \mathrm{CO}_{2}, \mathrm{CO}_{3}$ and $\mathrm{HCO}_{3}$ alkalinity. It was negatively correlated with dissolved oxygen (DO) (Table 2).

\section{Discussion}

Copepods were abundant in spring. The highest peak of copepods during spring was reported from India by George (1966) in fish tanks. Krishnamurthy and Visvesvara(1966) in Gandhisagor tank, while Patra and Azadi (1987) in the river Halda and Islam et al. (2000) in Bangladesh. Cyclops scutifer was observed perennial and dominant among the copepods in the present study. Other Cyclops sp. was frequent in occurrence. Heliodiaptomus and Mesocyclops were found to be seasonal. More or less similar findings were observed by Bhuiyan et al. (2008) in a fish pond in Rajshahi. All these genera were reported by various authors from Bangladesh, notably Das and Bhuiyan (1974), Khan et al. (1978) from Buriganga river, Chowdhury et al. (1989) from a fish pond and Islam et al. (2000) in a fish pond of Rajshahi city. The peak of copepods in spring may be due to the favourable conditions. Such as abundance of food organisms, favourable range of $\mathrm{pH}$ level, dissolved oxygen and alkalinity. Ferguson et al. (1982) considered temperature and food resources as the main factors responsible for changes in population densities and in the age structure of zooplankton.

Cyclops, Diaptomus and Merocyclops showed positive correlationship with $\mathrm{pH}$, free $\mathrm{CO}_{2}$ and $\mathrm{HCO}_{3}$ alkalinity. It was negatively correlated with temperature, dissolved oxygen (DO) and $\mathrm{CO}_{3}$ alkalinity. Mesocyclops showed positive correlationship with temperature, $\mathrm{pH}, \mathrm{CO}_{2}, \mathrm{CO}_{3}$ and $\mathrm{HCO}_{3}$ alkalinity. It was negatively correlated with dissolved oxygen (DO). More or less similar findings were observed by Islam et al. (2000) in a fish pond of Rajshahi City. From the present study it was observed that copepods were very much abundant in the pond which was favourable for planktivorous fish culture.

\section{References}

APHA (1976) Standard methods for the examination of water and waste water (4 th ed.). American Public Health Association, Washington, $1193 \mathrm{pp}$.

Bhuiyan A M and Asmat G S M (1992) Freshwater zooplankton from Bangladesh. Gazi Publishers, Dhaka, Bangladesh 32-151.

Bhuiyan A S and Nessa Q (1998a) Seasonal variation in the occurrence of some zooplankton in a fish pond. Bangladesh J.Fish. Res. 2: 201-203. 
Bhuiyan A S and Nessa Q (1998b) A quantitative study of zooplankton in relation to the physico-chemical conditions of a freshwater fishpond of Rajshahi. Univ. J. Zool. Rajshahi Univ. 17: 29-37.

Bhuiyan A S, Nahar Q and Islam M N (1997) Physico-chemical condition in relation to meteorological condition of a fish pond in Rajshahi, Uni. J. Zool. Rajshahi Univ. 16: 85-88.

Bhuiyan A S, Islam S N and Bhiuyan S S (2008) Seasonal occurrence of some copepods in relation to the physicochemical conditions of a fish pond in Rajshahi, Bangladesh. Fishing Chimes 28 : 39-41.

Boyd C E (1982) Water quality Management of Pond Fish Culture. Elsvier Sci. Pub. Co. Amsterdam- Oxford, New York 318pp.

Chowdhury A N, Begum S and Sultana N (1989) Occurrence and seasonal variation of zooplankton in a fish pond in relation to some physico-chemical factors. Bangladesh J. Zool. 17: 101-106.

Das N and Bhuiyan A L (1974) Limnoplakton of some inland water of Dacca city. Bangladesh J. Zool. 2: 47-51.

Ferguson A J D, Thompson J M and Reynolds C S (1982) Structure and dynamics of zooplankton communities maintained in closed systems, with special reference to the algal food supply. J. Plankton Res. 4: 523-543.

George M G (1966) Cooperative plankton ecology of five fish tanks in Delhi, India. Hydrobiol. 27: 81-108.

Islam A K M N and Mendes F (1976) Limnological studies of a jheel in Sher-E- Bangla Nagar, Dacca Univ. Stud. Pt.B. 24: 63-71.

Islam M N, Khan T A and Bhuiyan A S (2000) Ecology and Seasonal abundance of some zooplankton of a pond in Rajshahi. Univ.J. Zool.Rajshahi Univ. 19: 25-32.

Khan Y S A, Salam A M A and Ahmed M K (1978) Cladocera of the River Buriganga, Dacca, Bangladesh. Bangladesh J. Zool. 6: 73-83

Krishnamurthy K P and Visvesvara G (1966) Hydrobiological studies in Gandhisagar (Jumma Tank). Seasonal variation in plankton (1961-1962). Hydrobiol. 27: 501-514.

Mellanby H (1963) Animal life in Freshwater. (6th edition). Cox and Wyman Ltd. London 78-101.

Michael R G (1968) Studies on the zooplankton of a tropical fish pond. Hydrobiol. 32: 47-68.

Needham J G and Needham P R (1972) A guide to the study of Freshwater biology. $5^{\text {th }}$ ed. Holden-day, Inc. San Francisco, California, USA. 108 pp.

Patra R W R and Azadi M A (1987) Ecological studies on the planktonic organisms of the Halda River. Bangladesh J. Zool. 15:109-123.

Sreenivasan A (1967) The limnology of fish production in two ponds in Chinglipat (Madras). Hydrobiol. 32: 131-144.

Stirling H P (1985) Chemical and biological methods of water analysis for aquaculturists. Institute of Aquaculture, University of Stirling, Scotland 119.pp.

Tonapi G T (1980) Freshwater animals of India. Oxford and IBH Publishing Co. New Delhi 110001.

Ward H B and Whipple G C (1959) Freshwater Biology. (2nd ed.). John Willey and Sons. Inc. New York, London 1248 pp.

Welch P S (1948) Limnology. McGraw-Hill Book Company Inc.New York. pp. 218 